\title{
"My Own Way of Moving" - Movement Improvisation in Children's Rehabilitation
}

Wenche S. Bjorbcekmo, University of Oslo, Oslo, Norway

Email: w.s.bjorbakmo@medisin.uio.no

Gunn H. Engelsrud, University of Oslo/Norwegian School of Sport Science

Email: gunn.engelsrud@nih.no

\section{Abstract}

This article investigates the ways that children with different motor disabilities move in an improvisational context. We developed and implemented a one-year long movement improvisation program in which 12 children with different motor disabilities participated in weekly sessions under the practical leadership of two dance teachers and the researchers. The project's theoretical perspective and research approach are based on a phenomenological perspective that emphasizes movement as a personal, relational, and expressive phenomenon. The empirical material was developed and created through close observation and consists of the researchers' kinaesthetically lived experiences, video observations, and logbooks from the weekly movement improvisation sessions. In the article, we present and reflect upon five episodes from one activity regularly performed during the year. The article shows that movement improvisation can, over a period of time, offer children with motor disabilities an opportunity to explore their personal ways of moving together with others. The analysis explores how and why the children gradually felt secure enough to throw themselves into exploring their own movement possibilities and how improvisation promoted their desire to keep on moving.

\section{Introduction}

Children with defined disabilities have a legal right to health care and (re)habilitation services. ${ }^{1}$ In Norway, a stated aim in children's rehabilitation is to assist children in their own efforts to develop and achieve the best possible coping and functioning strategy and the greatest possible degree of independence and social participation. ${ }^{2}$ During the last decade, research within this field has focused on describing and evaluating change in children's motor function (Engelen, Ketelaar \& Gorter, 2007; Palisano et al., 2000; Smits et al., 2010; van Eck, Dallmeijer, Voorman \& Becher, 2009). In order to support and improve children's motor function, researchers have initiated several training programs to investigate what kinds of therapy, exercise and amounts of exercise may lead to increased motor function and "better" achievements (Bower, Michell, Burnett, 
Campbell \& McLellan, 2001; Christiansen \& Lange, 2008; Ketelaar et al., 2001; Odman \& Oberg, 2005; Shumway-Cook, Hutchinson, Kartin, Price \& Woollacott, 2003; Sorsdahl, Moe-Nilssen, Kaale, Rieber \& Strand, 2010; Salem \& Godwin, 2009). However, some researchers have questioned whether the great focus directed toward training, measuring, and evaluating specific motor functions might have a negative impact on the children's self-esteem (Gibson et al., 2009; Muldrej, 2000). They call for research that uses children's experiences as guidelines for the further development of movement-training programs within habilitation services. In accordance with this latter line of thought, we inquire why children with disabilities can not be encouraged to develop and explore their own personal way of moving and we endeavor to do just that.

Thus, the aim of this article is to investigate what will happen when children with different physical disabilities get the opportunity to explore their own personal way of moving over a period of time. In order to investigate this, we invited a group of children with various physical disabilities to participate in a movement improvisation group, which lasted for a period of one year. This program was developed by the researchers.

\section{Why Movement Improvisation?}

Steinsholt and Sommerro (2006) describe improvisation as a form of reflective practice that is applicable not only to artistic expression but also to other areas such as education, consulting, and management. A central element of movement improvisation is to always regard the participant as an active mover and the situation and environment as elements of the movements created. This understanding of body, movement, and environment as a dynamical relational entity is central to the phenomenology of Merleau-Ponty (2005) when he asserts that there is "no movement without a moving body which bears it uninterruptedly from start to finish” ( p. 312). He further explains "each voluntary movement takes place in a setting, against a background which is determined by the movement itself” (ibid, p. 159). In the movement improvisation group, these ideas inform the way we perceive children's movements in different situations and activities, as a dynamic exchange between the environment and the different children's bodies moving within it.

In movement improvisation an improvisational dance form is called "contact improvisation" (Novack, 1990). Several projects have used this dance form to give people with disabilities access to dance as both creative and performing artists (Østern, 2006). In movement improvisation, each person is viewed as unique, with their own specific movement potential, and the individual potentials are seen not only as valuable, but as decisively important for the individual; thus also for the collective movement expressions (ibid, p. 199). In this context, bodily and functional diversity are seen as a resource rather than a problem. This understanding of diversity and differences as valuable resources has particularly inspired us to apply an improvisational approach in our research.

As already mentioned, Steinsholt and Sommerro (2006) assert that improvisation is a form of reflective practice applicable to many different professional areas. In educational research it has been shown that when teaching, improvisation is a vital force in propelling children's learning processes (Sawyer, 2004, p. 17) as it promotes inductive discovery through what Berk and Trieber (2009, p. 33) call “deep learning.” Østern (2009) has explored dance improvisation with 
differently bodied dancers, as she calls the participants in her research, some of whom have a medical diagnosis that affects their bodies. She describes dance improvisation as a learning space where all the participants experience, learn and change in an individual and uncategorised way.

Regardless of what professional practice improvisation is a part of, Steinsholt (2006, pp. 1718/29) emphasises that in improvisation it is impossible for the improviser to escape from the imprint of the past. He, and others, highlight that although improvisation challenges clichés, habits and preconceptions, it always builds on existing knowledge and experiences. Improvisation takes place in the tension between individuality and tradition, between innovation and structure (Jurow \& Creighton, 2005; Sawyer, 2004; Steinsholt, 2006). Improvisation can, but does not necessarily open the field of movement, and it can be a driving force in exploration of the possibilities of performing individual movement expressivity in a context with others. This constituted another essential motivation for our choice to apply an improvisational approach. Thus, with the bodies that the participating children, the dance teachers, and the researchers have, we embarked on a year-long journey where we improvised, explored, and expressed our individual movements.

\section{Method and Material}

As already stated, a group of children with defined disabilities was invited to participate in a yearlong movement project. $^{3}$ The researchers organizing the program followed ethical procedures in recruiting ${ }^{4}$ the group of children. ${ }^{5}$ A total of 12 children, seven girls and five boys, between four and eleven years of age participated. Eleven of the children had a medical diagnosis and one had no diagnosis, but was still involved as a participant. ${ }^{6}$ The children had various kinds of walking and locomotion aids, including ankle-foot orthoses, ${ }^{7}$ crutches, walkers, walking sticks and/or manual or electric wheelchairs. Two dance teachers, with experience in movement improvisation, were employed to lead the weekly sessions, which took place every Monday evening from 6:00 till 7:30. The sessions were held in a small gymnastics hall that was usually emptied of all apparatuses that were not built into the room, in order to provide plenty of space for movement.

Van Manen (1990, p. 69) claims that the best way to enter a person's lifeworld is to participate in it. To us as researchers, this meant meeting the children participating in our study, being with them, talking with them and perhaps most importantly, moving with them. Van Manen's (p. 68) term “close-observation” was our source of encouragment. Moving together with the group provided us with emotional, kinaesthetic, and tactile body-to-body experiences. In moving and participating in the group activity, we tried to do what van Manen (p. 69) stresses as an essential element of close observation, namely to assume as close a relation as possible, while at the same time, retaining a hermeneutic alertness towards the meaning of the various movements and situations that evolved.

To preserve and recollect the living movement sessions, the dance pedagogues and the researchers made and exchanged logbook notes. The logbook served as a space in which to take a step back and reflect on the salient points and meanings of the various lived-through situations in the sessions. Writing in the logbooks became an essential resource for the development of the activities and for the analytical work during the whole year. In order to preserve and create research material, every session was also video-recorded. The video camera was positioned on a 
tripod in the same corner of the gym at every session. The camera was unattended most of the time, since everyone in the room was involved in the movement activities.

The analytical work has included reflective and interpretive writing based on readings of the researchers and the dancers' mutual logbook, as well as viewings of the recorded videos. ${ }^{8}$ Writing occupied a central position in the analytical work and required us to relive situations and experiences from the movement group. The produced material is dependent on our own bodily kinaesthetic experience of moving with the children as close observers. In analysing the material we aimed at what van Manen (1990, p. 86) describes as unearthing the initially "felt" or prereflective lived understanding or meaning of different experiences. The work of grasping the meaning of movements performed in the moving group demanded writing and re-writing, in an effort to write the experiences rather then to write about the experiences. During this process, we tried to bear in mind Henriksson and Saevi's (2009) ideas about the potential for language to give expression to the meaning of recollected lived experiences (p. 36).

Van Manen (1990) describes the process of writing as a process of "insightful invention, discovery or disclosure” (p. 79) Furthermore, he points out that the process of grasping meaning is not a "rule-bound process but a free act of "seeing" meaning" (ibid, p. 79). He holds that to see meaning is to reflectively analyze the "structural or thematic aspects" (ibid, p. 78) of the experiences. He poetically describes such structures or themes as "stars that make up the universes of meaning we live through" (p. 90). In writing and re-writing the perceived and experienced situations and events from a year in the movement improvisation group, we experienced that writing gave, as van Manen says, appearance and body to our thoughts (p. 127). In the writing, we tried to make sense of what different events and situations in the material were about by asking what the materials could tell us about the meaning of the phenomenon of movement experience and expression in improvisation. In our attempt to discover the meaning through writing and rewriting, we chose to follow up on and return to those episodes that spoke to us, both immediately during the movement improvisation itself and also later in our review of different parts of the material. These were the moments that seemed to have something important to contribute to our quest for a better understanding of what improvised movement might mean to children. To organize in written form the various significant episodes from the videos and logbook notes, we formulated headlines, titles, or themes that effectively describe the phenomenon of moving within an improvisational context (van Manen, 1990, p. 86).

In the following section we present, interpret and discuss experiential descriptions from selected video excerpts. All of these excerpts depict the same activity, "the fellowship dance," performed every week in the class. To illustrate the continuing development and change in movement in the group, the selected excerpts cover the period from $29^{\text {th }}$ of January to $4^{\text {th }}$ of June. Within this frame activity, the selected excerpts were among those that struck us as especially illuminating in terms of what motion might mean to children within an improvisational context. We also feel that they depict important movement experiences and expressions that could shed light upon what it means to children to improvise and explore their personal way of moving. 


\section{Movement Improvisation and "My Own Way of Moving”}

Each evening, for the fellowship dance, the leader invited one child to suggest one movement. The child who invented the movement of the evening performed it for the group. Afterwards the whole group performed the movement together. Week by week the dance came to consist of an increasing number of movements, each supplied by one of the participating children. Within the frame of the activity, each participant could perform all the different movements in their own way subject to two conditions: everyone had to stay in the same position in relation to each other throughout the dance and no movement should raise us higher than our own height when sitting on the floor. In the following episodes, we have given the children fictional names in order to stress their individuality as well as to ensure anonymity.

\section{Giving and Receiving Movements}

Giving and receiving movements was one of the main elements of the fellowship dance. The fellowship dance was considered suitable to promote relational attentiveness in the group and an awareness of our shared contributions to individual and collective movement. The following is an excerpt from a written account of the movement class of March $19^{\text {th }}$, based on a video recording made that day.

Ten children and three adults are sitting in a circle on the floor. The opening welcoming activity has just finished and we are preparing for the fellowship dance. In order to perform this dance we need more space, so all the participants move about until they have enough elbowroom. Then we look at Emma. She is the one who is going to make and show her movement contribution this evening. Emma sits quietly. Everyone is waiting, including Christopher and Fillip, even though they have already started performing the initial movement of the fellowship dance. Shortly afterwards they sit down too. All the time the leader is attentively facing Emma. Emma still sits quietly, slightly stooped over and looking down. Then she raises her head, slowly shrugs her shoulders, stretches out and lifts both arms with her palms upwards, tilts her head and lifts her eyebrows and with a cautious smile looks at the leader. The leader waits for a while and then asks: "Is this what we're going to do?" and imitates Emma's movement. Emma nods approvingly. Then it is decided that we are all going to make Emma's movement. We make her movement three times. The fellowship dance now consists of seven movements, all of which we each perform in our own way.

Our first impression is that Emma is expressing that she does not know what to do. Her body language conveys insecurity. According to Merleau-Ponty (2005), the meaning of a gesture is in its expression - there is nothing behind it, it is "intermingled with the structure of the world outlined by the gesture" (2005, pp. 214-216). Based on this, Emmas's movement can be understood as an expression of insecurity. At the moment she makes her movement, she seems to be in a position of "not knowing." This "not-knowing" situation fills the group with a tension that 
mirrors Emma's expressed insecurity. This transmission illuminates the interconnection and interrelation of the body with other bodies and the world. Merleau-Ponty's (1968, p. 148) concept of chiasm can help to explain this phenomenon, defining the relation between Emma and the rest of the group in this particular "waiting" situation. Feelings and understandings float between us via osmotic processes so that we recognise, feel, and understand that Emma does not know what to do and cannot at that moment think of a movement. From a phenomenological point of view however, her body knew about the not knowing and expressed it in a movement. In this way Emma's embodied knowledge became visible to us.

Emma's “I don’t know” movement left the group for a few seconds with a question, since we initially interpreted it as a movement that was not meant to be included in the fellowship dance. For some seconds we wondered: what now? what next? what will the leader do? The leader's waiting attitude could indicate an assumption that Emma might do more, make another movement or decide that the movement was indeed intended to be included in the dance. Emma made no further movement and the leader suggested, in the form of a question, using the movement she had performed. When Emma nodded, the situation was subtly adjusted. Emma's nod confirmed that her movement was to be included in the dance.

Steinsholt (2006) maintains that in improvisation a mistake or, as in our case, a movement not originally intended to be a contributed movement, is seized upon and invited in, and it becomes part of the creative development of the activity. Jørgensen (2006) describes the improviser as someone continually challenged to use her or his sensitivity to a given context in order to respond (p. 46); it is through sensitive dialogue that the improviser builds companionship and creates meaning. The leader's thoughtful pause and resourceful response also illustrates what van Manen (1990) calls pedagogical tact. Emma's nod welcoming the leader's suggestion marks the presence of dialogue and the possibility of companionship. So far, two themes can be abstracted from the above interpretation. We have called the first "the agony of having to make a contribution" and the second "the virtue of waiting."

\section{The Agony of Having to Make a Contribution}

In the above situation, the group expected Emma to perform a movement that would contribute to the fellowship dance. Steinsholt (2006) argues that in the context of improvisation, such situations challenge the person (p. 41) —in this case Emma - to throw herself into movement, to take a risk and let go. He maintains that this throwing oneself into an activity, for instance movement, is one of the main aspects of improvisation. Steinsholt emphasizes the importance of liberating oneself from fixed ideas and giving oneself up to the unknown, risky aspects of a situation, which in this case was the creation of a movement within a landscape of possible movements and ways of moving.

From a phenomenological perspective, Emma's hesitation and her bodily expressed insecurity can also be understood as illustrating the complications of "being my body for me and my body for others.” Emma's discomfort could be seen as an expression that, at that moment, she was being her body for others more than for herself (Merleau-Ponty, 2005, p. 122). The ordinary, taken-for-granted way of moving as a response and attunement to daily life and actions was displaced at that moment. Emma, as the body she is, and also like the rest of us, does not "weld 
together individual movements and individual stimuli, but acquires the power to respond with a certain type of solution to situations of a certain general form” (Merleau-Ponty, 2005, p. 164). Sheets-Johnstone (1999, p. 516) explains that habitual being is characterized by non-separation of thinking and doing as well as a non-separation of sensing and moving. Thinking, sensing and moving are qualities absorbed by the moving body as a whole when everything seems normal, but if the above situation appeared unusual, unfamiliar or uncomfortable to Emma, this would hamper her in the task of thinking of a movement.

As the situation turned out, Emma's movement was given value as communication. Her movement expressing "not knowing" was taken as a significant expression of the situation. It is not always easy to understand or apply the freedom to let oneself blossom that Steinsholt (2006) claims is the great potential of improvisation. In this respect, what Merleau-Ponty (2005) points out is important, that movement is always created and performed in a space that is not empty, since movement and background or environment are not separate, but are two elements of the same totality (p. 159). Since improvisation is concerned with dialogue, the actions of the leader as well as Emma, and the response and interaction between the two are all vital to the outcome of the situation.

\section{The Virtue of Waiting}

The leader might have wondered how she should respond to Emma's movement. Her attentive focus on Emma and her patient waiting had made Emma's movement possible. As already discussed above, such a movement or gesture does not make us think of "I don't know," it is "I don't know;" the meaning is not behind the gesture, it is the gesture, as explained by MerleauPonty (2005, p. 214). However, instead of confirming that Emma does not know what movement to make, the leader welcomes her movement as a significant contribution by asking her: "Are we going to do it like this?” In accordance with Steinsholt (2006), the leader follows a fundamental principle of improvisation by seizing upon and welcoming Emma's movement, and thereby letting her in. Emma is treated with respect. Her movement is as good as anyone else's movement or any kind of movement. According to Steinsholt and Sommerro (2006), approving of what has actually happened is at the core of improvisation.

Sheets-Johnstone (1999) argues that in dance improvisation, movements are not limited to what is culturally identified as "dance movements," but can also incorporate movements and gestures from everyday life that have certain culturally recognised meanings (pp. 488-489). Østern (2006) also points out that this is a characteristic of improvisation, especially contact improvisation. Sheets-Johnstone adds that performing such movements does not make the dance or the particular movement symbolic. Emma's contribution is not about "not knowing," instead it is about knowing who she is at that moment. Sheets-Johnstone state, in dance improvisation every movement is filled by its own range, rhythm, power, and intricacy, which are all fundamental for the experience of self and others. Emma's movement in that particular session was a new contribution that was permitted and welcomed. The movement was welcomed for its own perceptual dynamic and kinaesthetic expressiveness.

The moment during which we waited for Emma's movement illustrates one of Steinsholt's (2006) points: in improvisation, one has to be prepared for spontaneous confusion and the torment 
of insecurity (p. 41). The improvisers must accustom themselves to the torment of insecurity by departing from fixed rules and cultivating the ability to wait and be passive, and also to have the courage to throw themselves into activity, for instance movement. This makes the participants susceptible. If group members are to meet the condition that they depart from fixed rules and place themselves in a vulnerable position, there must be mutual trust within the group. The point of heteronomy is to "say yes" to the other's request as an ethical obligation and responsibility, and in so doing, to create mutual trust and surrender one's freedom to the freedom of the other without losing oneself and one's own freedom (Alterhaug, 2006, pp. 90-91; Steinsholt, 2006, p. 42).

As we have indicated, an improvisational approach allows room for movements to express themselves. In Emma's case, this involved seizing upon what actually happened. The episode revealed how a welcoming and approving attitude made Emma comfortable enough to throw herself into accepting her own movement, to feel that her own movement, as it happened, was good enough and was a significant contribution to the fellowship dance.

\section{Performing Given Movements}

Sharing movements with each other and performing them in our own way was another central element of the fellowship dance. The episode below is the continuation of the one above.

Now that Emma has given her movement contribution and we have all tried it, we are ready to perform the whole dance as it now stands. Each movement is to be done twice, and the child who "owns" the movement has to count aloud: one, two. Susanne's movement is the first one and she spins round and round on her hands and knees - once and then a second time. The whole group is moving around. Some spin sitting on their bottoms, others by turning their heads from side to side. Most spin on hands and knees. After Susanne's movement comes Gustav's. Gustav is ready. He raises both arms up in the air, turns slightly to the left and then flings himself sidewise to the right. His left leg raises a little as he reaches the floor with a muffled bang. "One" he counts loudly. Several participants are flinging themselves sidewise onto the floor while others remain sitting or fling themselves half-way down, slapping one or both hands on the floor. Gustav raises himself to a sitting position. "Two" he says as he flings himself down onto his right side. He does this a third time as well, and one of the adults enthusiastically follows him this time too. (Episode from videotape $19^{\text {th }}$ of March)

When Gustav showed his movement contribution for the first time, Fillip said; "I can't do it. I'll hurt my head." The leader answered: "Then you have to make sure you don't do that." Soon afterwards she added: "Maybe you can stop yourself with your hands or maybe not throw yourself so vigorously or so fast." (Episode from videotape $29^{\text {th }}$ of January)

By performing Susanne's, Gustav's, and the others' movements, our attention was drawn to the performance of the others. Even when everybody is allowed to make all the movements in their own way, performing them seems to involve questions concerning one's own competence and performance possibilities. To compare oneself with others is unavoidable in social situations. In 
this situation it becomes quite clear that there are huge differences in how a movement shown by its owner is received. For instance, in this case Fillip indicated that he could not perform the movement without hurting his head.

When everybody performs Susanne's spinning movement and Gustav's side-fling, the different personal bodily expressions can be seen as snapshots of our different kinetic repertoires, according to Sheets-Johnstone (1999): “our individual repertoires are ultimately a measure of how far we have grown into the bodies we are” (p. 136). There are several ways of interpreting the decision of some of the participants to spin sitting on their bottom or make spinning movements with their neck while most of us are spinning on hands and knees like Susanne. One interpretation is that this constitutes evidence that some were being more creative by spinning in their own way, an alternative interpretation is that they do not have the capacity or kinetic repertoire to spin on hands and knees. The question of capacity or kinetic repertoire and creativity may also be linked to a question of courage. Steinsholt (2006) maintains that improvisation requires the courage to "put oneself at risk." An intermingling of capacity, creativity and courage was a vital element in our performance of the all the movements in the fellowship dance.

\section{Capacity, Creativity and the Courage to Put Oneself at Risk}

With regard to capacity and capacity building, Sheets-Johnstone (1999) argues that in moving oneself the mover discovers more and more "I cans." She describes this realm of kinetic "I cans" as an open-ended realm of possibilities (p. 136). We performed Susanne's, Gustav's, and the others' movements as the bodies we are and with the movement repertoire that each of us possesses. In addition to helping us explore our movement repertoire of "I cans," however, the episodes can also be perceived as revealing a repertoire of possible "I cant's." An "I can't" was present when Fillip said "I'll hurt my head," and when other children said they could not perform the movement or went frequently to the bathroom or momentarily became extremely tired when some movements were being performed.

We performed the fellowship dance as the bodies we are. According to Merleau-Ponty (2005), every movement performance is rooted in one's ever-present reciprocal directedness or "motor intentionality" (p. 157) or, as Todes (2001) calls it, "poise” and to be poised is, according to Todes to be "in touch with our circumstances" (p. 65). Further he states that "[t]o be poised is to be self-possessed by being in touch with one's circumstances” (p. 65). Dealing with one's circumstances means responding to them, and as Steinsholt (2006) emphasises, participating in improvisation is about taking risks.

This sensing, sentient body-subject is what Abram (2005, p. 58) describes as an open form continually improvising its relationship to objects, other persons, and the world. Thus in performing the fellowship dance we committed ourselves to adapting and attuning ourselves to the environmental landscape of this dance from moment to moment. Merleau-Ponty (2005) has this to say about the relationship between an individual and her surroundings:

[Every individual's] cognitive life, the life of desire or perceptual life, is subtended by an 'intentional arc' which projects round about us our past, our 
future, our human setting, our physical, ideological and moral situation, or rather which results in our being situated in all these respects. It is this intentional arc which brings about the unity of the sense, of intelligence, of sensibility and motility. (p. 157)

Thus in performing the movements of the fellowship dance and in being allowed to do so in our own way, our previous movement experiences - of participating in previous sessions, in therapy, school activities, gym lessons, playing with friends - mingled with our performance in the dance, as we carried out Susanne’s spinning movement and Gustav’s side-fling.

Children with disabilities have a great deal of experience in dealing with and taking risks in moving. They also have extensive experience of failure in this area and of cultural and social devaluation of their movements. Todes (2001) states that experiencing failure in the eyes of others results in a loss of poise, which is the awareness of a gap between oneself and one's circumstances:

It is only in failure of response, and loss of poise, that a distinction appears between what I was trying to do and what I did. When I act in an effective, poised way, it is not merely that what I was trying to do is in agreement with what I (distinguishably) did do. Rather, there is no gap at all between my own action and what it made of my surroundings, so that no agreement or disagreement could be noticed; there were no two things to compare, but only the perfect fit of me-in-my-circumstances. (p. 70)

For a child in the movement class, the perfect fit of me-in-my-circumstances might be better served by leaving the room to go to the bathroom, by claiming that "I'm so tired that I have to rest” instead of participating in the movement, and even better served by declaring a lack of ability or talent to perform certain movements. For each child, moving in his own way, with his own capacity or ability to make a movement like Gustav's side-fling is also a reflection of his creativity in finding solutions that allow him to cope with his circumstances and not only with his own body and its movements. However, Steinsholt (2006) asserts that an essential characteristic of improvisation, besides individuality, creativity, and personal expression, is fellowship. He points out that improvisational practice has always been concerned with building fellowship and developing new ways of thinking about what it means to participate in human relationships (ibid, p. 34).

According to Berk and Triber (2009), building trust is decisively important in improvisation, both in order to build fellowship and to provide a basis for participating and daring to be creative in one's own way. They emphasise that it takes time to establish and provide an environment where the participants can feel free to explore and create their own way of performing movements, for instance the spinning movement that Susanne contributed to the fellowship dance.

The capacity and creativity required of each child to perform the other children's movements in his or her own way depended on the children feeling secure enough in that particular situation to put themselves at risk when dealing with all the different movements of the fellowship dance. We found that the children's own capacity of kinetic repertoires and creativity seemed to be stimulated by experimenting and playing with the movements of the fellowship dance. The 
meaning of "my own way of moving" in improvisation is rooted in the attitudes expressed in the actual environment. "My own way of moving" is related to a feeling of security, a desire to be in touch with one's circumstances, and to devise a means of performing a certain movement, whether by mimicking, duplicating or in some other way transcending the movements of others. Performing the fellowship dance required each participant to weigh the possibility of success against that of failure, which in this case involved crucial bodily, relational, and situational considerations.

\section{Playing with the Movements of the Dance}

The movement group developed the fellowship dance over a number of weeks. Before the end of the year, all the children had contributed with a movement and we had performed the whole dance several times. We then loosened up or changed the rules in terms of space, time, succession of movements, and our position in the room. This was intended to challenge the participants to further explore the movements, the dance itself, and their own ways of moving performing the dance.

After having performed the fellowship dance as usual, the leader said: "Now we're going to do it differently. We're going to play with it." After a short explanation of the new rules we were split into two groups. For more than half an hour each group moved, tried out different ways of performing the movements and talked about movement. While moving, the members of each group focused intently on playing with the movements within their own group. After a while the leader told the two groups to show each other how they had been working with the movements of the dance. The first group consisted of three children and one adult.

Anne, Johannes and the group leader are standing with their backs against the wall while Emma is sitting on the floor facing them. The audience, the other group is sitting on the floor a little behind and to the right of Emma. There is complete silence. The music starts and the dance begins. Slowly arms, bodies and legs move against the wall, making smooth sweeping sounds. The performers stretch out and bend their arms and twist their bodies, first in one direction and then another. Johannes stops. He stands still. Anna rolls herself against the wall, stops and bends over with her arms above her head. Johannes looks at Anna and the leader. Then, facing the wall, he stretches his arms very high and starts to swing his body from side to side. At the same moment Gustav, who is in the audience, does his side-fling movement and Jenny, also in the audience, gets up on her knees, stretches both arms high up and swings her whole body. Emma's arms are moving like wings in the same rhythm as the bodies against the wall. Arms, legs and bodies move towards, away from, over and under each other. Suddenly the smooth, slow rhythm is interrupted by rapid repeated up-anddown movements, first with one leg, then the other. The show comes to an end when the leader of the other group slowly turns off the music. Emma turns her head towards the audience. All the performers are looking at us and smiling. We, the audience, smile and applaud. (Episode from video recording $4^{\text {th }}$ of June) 
What especially attracted our attention in this episode, as we observed the two groups, was the concentration and commitment we experienced while we were trying out different ways of performing the movements of the fellowship dance. While playing with the movements, everyone seemed deeply present and relationally engaged in the activity of moving. We were all absorbed in moving in a different way than we had been at the beginning of the year. At that time, when exploring ways of moving in response to the various tasks, the children often stopped the activity quite quickly, saying: "I’ve finished," "I’ve done it," or "I've tried all the movements." At the end of the year, movement seemed to stimulate more movement and new and different ways of performing the same movements over a continuum. The participants were no longer just performing and completing the movement or the dance. but seemed almost possessed by moving for the sake of moving. As shown in the above episode, the performers did not stop until the leader of the other group turned off the music. In playing with the fellowship dance, in improvising on the movements of the dance, the only goal was to move and to dance rather than just to complete the movement or the dance.

\section{The Desire to Move and to Keep on Moving}

The desire to keep on moving that we experienced and observed may be related to what SheetsJohnstone (1990, p. 489) describes as "kinetic intelligence forcing its way" into the immediate situation by moving and shaping and re-shaping given and known movements. She argues that movement improvisation consists of more than making explicit choices about movements or specific ways of moving, but that it also calls forth new kinetic circumstances that shape the individual's way of moving in an actual situation. In playing with and improvising the fellowship dance, everyone kept on moving in their own individual way as well as in a collectively driven continuum of movements that arose there and then. In playing with the fellowship dance and keeping on moving, our bodily kinetic intelligence forced its way into the movements and ways of moving we created and improvised. This is also related to what Gendlin (1992) calls "coming” as a characteristic of the body:

[...] appetite comes, also orgasm, tears, sleep. You recognize the bodily nature of such comings. Emotions also come in this way. You can feign joy or anger but to have them, they must come. So also does muse come, when she is willing and not otherwise. And new ideas, the lines of a new design, and steps of therapy come in this way.” (p. 202)

During the show the performers kept on moving, and the movements seemed to just come, to arise of themselves, even though they also stopped sometimes, as when Johannes stood still at the wall. At the moment of not moving he seemed content and not disturbed by his own stillness as he watched his companions moving. Nor did the others seem to be disturbed by Johannes not moving. They continued with their own movements and accepted Johannes's stillness, so that his stillness became an element of their collective movement.

Steinsholt (2006) describes improvisation as an activity or a practice of waiting for the moment when what happens, happens. It is a series of moments that occur in a state of "notknowing" or through a reinforcement of the tension arising from not knowing what will happen in what does happen (p. 25). When Johannes suddenly started moving again it was as if other 
performers' movements were being transmitted. Anna's movements seemed to inspire him to stretch his arms higher and higher as she stretched hers. This alternation between not moving and moving had an effect, it created a tension, and as Steinsholt (2006) puts it, it also created an expectation in the audience. Improvisation is playing together, and in performances it is at its best when the audience joins in. Steinsholt refers to Gadamer when he emphasises the importance of the audience's primed attention as a contribution to improvisation that creates a complex dialogical play, essential for grasping the meaning of the moment (p. 36).

With respect to "keeping on moving," Merleau-Ponty (2005, p. 125) maintains that every stimulus applied to the body ${ }^{9}$ arouses a potentiality of movements rather than an actual movement. Thus, seeing the display of others' movements and moving themselves aroused a potentiality of movements in all the participants, both the performers and the audience. It was as if the individual movements slowly drifted and floated into each other, not only between the performers but also into and between those in the audience. As the episode shows, this caused members of the audience like Gustav and Jenny to throw themselves into visible movement. The boundary between the performers and the audience fluctuated and dissolved. This dissolution of the boundary between performers on the one hand and the audience on the other is what Østern (2006) calls a characteristic quality of dance improvisation as opposed to the built-in distance between the disciplined stage dance and its audience. In moving together, the distance between the children, the leaders and the researchers disappeared in our improvisations. In movement improvisation, everyone is able to move, since diversity and differences are accepted, welcomed and seen as a productive resource rather than a problem. Improvising and playing with movements seem to stimulate the desire to move and keep on moving.

\section{Reflecting on Movements Seen and Performed}

As mentioned above, talking about movement expressions and movements expressed was an integral part of the sessions, since we wanted to provide time and space for reflecting on watching others' movements and performing movements for an audience. Thus, after the show in the above episode, the dance leader asked the audience:

"Did you see what the performing group has been working with?" "Yes," Gustav replied. "I saw you were doing my movement, but (he hesitates a little) you didn't imitate me ... you should (he stops, then continues) it's a difficult movement." "Yes it is," replies the leader. Gustav is asked what he thought about the performing group making their own version of his movement. He does not answer directly, but says: "I saw Johannes was working really well." Susanne is next and says: "I think it looked very good with someone standing and others sitting." Lisa, also one of the audience, says: "I thought the slow movements were very nice." She adds: "I move fast." And shortly afterwards: "I think it's difficult to move slowly."

The performers are also asked to say what it has been like to put on the show. With a smile, Anna explains: "I think it was a bit strange. It was strange to do it like this." Emma agrees with Anna, and adds: "It was fun and fine-my movement became so strange and different." (Episode from videotape $4^{\text {th }}$ of June). 
This episode shows how the children paid attention to each other and also commented, not only on what they had seen, but also on what it had been like to see the others' movements and ways of moving. When Gustav says, "Yes, I saw you were doing my movement," this could show how observing the performance made him recognise and feel in his own body the performers "doing his movement." He also recognised and felt bodily that they did not imitate him exactly or make the movement "his way." In this sense, the experience is linked with the question of "my own way" and "the other's way” of moving. Gustav's hesitation and his pause after saying "you didn't, you should..." indicates that he had to some extent adopted an attitude of appreciation; the attitude that what is being shown is significant and good as it is. His reaction shows how challenging it is to act in accordance with several different cultural understandings of movement-the everyday social understanding, that of the health services and the one implied in improvisation. In this context, Gustav's approving statement, "I saw Johannes was working really well," is a good illustration of this intermingling of different discourses and understandings about movement. Comments from Susanne and Lisa also seemed to arise from their bodily felt experience of the performance. When Susanne says that the different positioning of the performers is nice and good, the pattern of the performer's positions might have meant something special to her or she might have been simply expressing appreciation of the difference between Emma sitting on the floor and the others standing against the wall. Lisa's comment on the speed of the movements, when she says that she thinks slow movements look nice and at the same time says that she herself usually moves fast and that she feels moving slowly is difficult, shows how watching and attending to others' movements is a bodily felt experience that is intimately related to the actual situation, previous experience, one's own body and possible movements and the movements and bodies being observed. The children's comments and reflections gave greater significance to the other children's movements and the bodily felt transfer of movements between the performers and the members of the audience. Movement improvisation promotes the felt and immersive qualities of movements and moving, and as shown above, it promotes a desire to keep on moving.

\section{Movements Felt, Transmitted and Desired}

In playing with the movements of the fellowship dance, the children threw themselves into moving and gradually began making use of what they heard and saw and felt inside themselves, in their bodies and in their movements. Wigerstrand (2006,) calls this a significant element of improvisation (p. 129). Daring to put oneself at risk by moving in accordance with what one feels comes from the confidence that one's ways of moving are accepted and welcomed as they come and as they are. According to Gendlin (1997), the "felt sense" is a capacity and characteristic of the body. The body feels and knows. Block and Kissell (2001) also maintain that this is vital in improvisational dance (p. 10). They describe improvisation as an awakening of the body as knower. The body knows what it wants to do as it senses and feels our impulses. In the improvised fellowship dance where Emma showed her movement for the first time, the children's bodies knew what they wanted to do both when Johannes stood still and when Emma shrugged her shoulders and stretched her arms forward with the palms turned upwards. Movements come when given time and space, because the body knows what it wants to do.

While Gendlin (1992, p. 194) describes coming as a characteristic of the body, Todes (2001, p. 68) talks about the body's need. He defines this as our field of experience, and states that our needs can be definite only to the extent that fulfilling them seems possible. The closing of the gap 
between oneself and the field of one's experience is about satisfying needs - a spatiotemporal lifefield in which "finding is the satisfaction of seeking," which in turn is driven by need (Todes 2001, p 67). In playing with the fellowship dance and all the other improvisation activities, we all needed to find different ways of moving and performing the different movements and dances. In the fellowship dance this process made it possible to close the gap between need and satisfaction, and thus to be poised. According to Todes, when poised, there is no gap at all between one's own actions and what they make of one's surroundings, so that there is no agreement or disagreement. "There were no two things to compare," (Todes 2001, p. 70) but only the perfect fit of the performers putting on the show and their circumstances, which combine in performing the dance for the audience. The performers' smiles at the end of the show seemed to express satisfaction with their performance. Emma's momentary turn towards the audience, the performers' smiles and Anna's and Emma's smiles and comments that doing the show had been "fine," "fun," and "strange" seem to indicate that they felt in touch with the circumstances of putting on a movement show and that they had found satisfaction in the ways they moved. When in touch with one's circumstances in movement improvisation, the improvisation is a playful experience that is almost magical, that produces a feeling of being, in Steinsholt's (2006) words "on the other side of nowhere” (p. 25). As the fellowship dance show indicated, the improvisation sessions gave the participants the opportunity to seek and find ways of moving and of letting movements come as they came. It also showed how movement improvisation facilitates the desire for movement and stimulates a need to move, and in doing so allows for the possibility of finding satisfaction and experiencing a feeling of being "on the other side of nowhere," where moving for moving's sake is the driving force.

Our movement improvisation sessions were a year-long journey of exploring movement and our bodies in motion. Steinsholt (2006) holds that creativity in many areas, including movement, and finding "one's own way" depends on a certain amount of luck, which is related to struggle and frustration in the process of trial and error (p. 35). Thus being creative and exploring one's own way of moving is not only closely linked with the moving subject's own body but is also to a large extent a question of contextual attitude.

\section{Conclusion}

In this article, we have discussed the phenomenon of moving in an improvisational context. This context entailed encouraging all the participants to move in their own way. The analyses from movement sessions with children with a defined disability have uncovered how the children contributed to fill the space with improvisation and discovered new movements that they took advantage of. By presenting and reflecting on episodes from one activity, the fellowship dance, we have illustrated how the children needed time to adjust to the improvisational praxis. When they discovered the "new" possibilities of moving, they gradually felt more secure in exploring movements and their "own way of moving." Providing each other with the freedom and opportunity to move in our own way created trust and helped the children to throw themselves into exploring ways of moving and movement possibilities. When they felt increasingly secure in the improvisational context they trusted that their performing movements were "good enough". When they felt "good enough" they were less likely to be caught up in "I can't" and showed more 
confidence in their own ways of moving. They increasingly moved in the space with a growing satisfaction and pride in their movements and bodies.

Over one year of improvisation sessions, the children proved to us that they possessed a large variety of movement possibilities. We learned that improvisation can function as a pedagogical tool in the creation and exploration of moving. During the year, the children improved their "functional ability" and also increased their movement competence. The movement competence became particularly visible in a desire to keep on moving in a continuous and exploratory way. The meaning of finding "my own way of moving" seemed to be closely linked with the feeling of being in touch with one's circumstances while moving. When the children's way of moving was welcomed and regarded as significant, they found satisfaction in moving, and were inspired to keep on moving - and to enjoy moving in their own way.

\section{Acknowledgements}

We are grateful to The Norwegian Fund for Post-Graduate Training in Physiotherapy for the financial support that made our project possible. We would also like to thank Magnar Mathisen, head of the section for children's rehabilitation at the Østfold Hospital Trust, Norway, for help in recruiting participants to the project. We would also like to thank the anonymous reviewers and members of the Editorial Team for helpful comments on earlier drafts of the article.

\section{Endnotes}

1 World health organization (WHO) about health and human rights: http://www.who.int/hhr/en/. Norway L02.07.1999 nr. 63 Lov om pasientrettigheter. The UN Convention on the Rights of the Child, see points 23 and 24: http://www.regjeringen.no/en/dep/bld/Documents/Guidelines-andbrochures/2000/barnekonvensjonen-engelsk.html?id=419254

2 “Children's habilitation and rehabilitation are planned, time-limited processes with clear goals and methods, where several actors participate in providing the necessary assistance to the user's own efforts to achieve the best possible coping and functioning strategy and social participation." (Chapter 1, section 2 of the Norwegian regulations of 2001).

${ }^{3}$ This was part of a research project in which we explored how children with different disabilities experience moving in daily life, in play and activities with their friends and family, including how children experience moving in the movement improvisation concept we developed. Before carrying out the project, approval was attained from the regional committee of medical research ethics.

${ }^{4}$ Written information and invitations to participate were handed out to the professionals to pass on to their clients. An invitation accompanied by information was also published in the bi-annual course catalogue dispatched by the centre to all its users, which included children and their families and other relevant professionals in all the municipalities in the county. 


\footnotetext{
${ }^{5}$ All those who gave a positive response received written information together with a consent form. Eleven children started in the autumn of 2006. Two of them decided to leave the project after the first half year. One child started in January 2007 and participated in the last half year. We decided in the first autumn that the project should run for a full year.

${ }^{6}$ Eleven of the participating children had a medical diagnosis. Six were diagnosed with cerebral palsy, three with spina bifida or myelomenigocele, and two with hereditary spastic paraplegia. One child had no medical diagnosis and was not suspected of having one. This child participated with her twin sister.

${ }^{7}$ http://en.wikipedia.org/wiki/Ankle-foot_orthosis.

${ }^{8}$ The video material consisted of 29 videos representing about 40 hours of recording. The logbook consisted of 69 A4 pages.

${ }^{9}$ He added “of the normal person”
} 



\section{References}

Abram, D. (2005). Sansenes magi - $\AA$ se mer enn $d u$ ser [The spell of the sensuous - perception and language in a more-than-human world, 1996]. Oslo, Norway: Flux Forlag.

Alterhaug, B. (2006). Mellom panikk og kjedsomhet. [Between panic and boredom]. In K. Steinsholt \& H. Sommerro (Eds.), Improvisasjon. Kunsten å sette seg selv på spill (pp. 7193). Norway: N.W. Damm \& Søn AS.

Berk, R. A. \& Trieber, R. H. (2009). Whose classroom is it, anyway? Improvisation as a teaching tool. Journal on Excellence in College Teaching, 20(3), 29-60.

Block, B \& Kissell, J.L. (2001). The dance: Essence of embodiment. Theoretical Medicine, 22, 515.

Bower, E., Michell, D., Burnett, M., Campbell, M.J. \& McLellan, D.L. (2001). Randomized controlled trial of physiotherapy in 56 children with cerebral palsy followed for 18 months. Dev Med Child Neurol, 43(1), 4-15.

Christiansen, A.S., \& Lange, C. (2008). Intermittent versus continuous physiotherapy in children with cerebral palsy. Dev Med Child Neuro, 50(4), 290-3.

Engelen, V., Ketelaar, M. \& Gorter, J.W. (2007). Selecting the appropriate outcome in pediatric physical therapy: how individual treatment goals of children with cerebral palsy are reflected in GMFM-88 and PEDI. J Rehabil Med, 39(3), 225-31.

Gendlin, E.T. (1992). The wider role of bodily sense in thought and language. In M. SheetsJohnstone (Eds), Giving the body its due (pp. 192-207). New York: State University of New York Press.

Gendlin, E.T. (1997). Experiencing and the creation of meaning. A philosophical and psychological approach to the subjective. Evanston: Northwestern University Press.

Gibson, B. E., Darrah, J, Cameron, D, Hashemi, G, Kingsnorth, S., Lepage, C et al (2009). Revisiting therapy assumptions in children's rehabilitation: clinical and research implications. Disability and Rehabilitation, 31(17), 1446-1453.

Jørgensen, S.H. (2006). På merkelig vis, på sparket, og smått på trynet.[In a strange way, off the cuff, and falling flat on one's face]. In K Steinsholt \& H. Sommerro (Eds.), Improvisasjon. Kunsten å sette seg selv på spill (pp. 45-69). Norway: N.W. Damm \& Søn AS.

Jurow, S. A. \& Creighton, L. (2005). Improvisational science discourse: teaching science in two K - 1 classrooms. Linguistics and Education, 16, 275-297. 
Karlsen, G. (2006). Stilt overfor det som ennå ikke er.[Facing that which does not yet exist]. K Steinsholt \& H. Sommerro (Eds), Improvisasjon. Kunsten å sette seg selv på spill (pp. 239-259). Norway: N.W. Damm \& Søn AS.

Ketelaar, M., Vermeer, A., Hart, H., van Petegem-van Beek, E. \& Helders, P.J. (2001). Effects of a functional therapy program on motor abilities of children with cerebral palsy. Phys Ther, 81(19), 1534-45.

Merleau-Ponty, M.(1968). The visible and the invisible. Evanston: Northwestern University Press.

Merleau-Ponty, M. (1962/2005). Phenomenology of perception. (C. Smith, Trans.). London and New York: Routledge Classics.

Mulderij K.J.(2000). Dualistic notions about children with motor disabilities: Hands to lean on or to reach out? Qualitative Health Research, 10, 39-50.

Novack, C. (1990) Sharing the dance: contact improvisation and American culture. Madison: University of Wisconsin Press.

Odman, P. \& Oberg, B. (2008). Effectiveness of intensive training for children with cerebral palsy - a comparison between child and youth rehabilitation and conductive education. $J$ Rehabil Med, 37(4), 263-70.

Palisano, R.J., Hanna, S.E., Rosenbaum, P.L., Russell, D.J., Walter, S.D., Wood, E.P.....Galuppi, B.E. (2000). Validation of a model of gross motor function for children with cerebral palsy. Phys Ther, 80(10), 974-85.

Salem, Y. \& Godwin, E.M. (2009). Effects of task-oriented training mobility function in children with cerebral palsy. NeuroRehabilitatio, 24(4), 307-13.

Sawyer, K. R. (2004). Creative teaching. Collaborative discussion as disciplined improvisation. Educational Researcher, 3(2), 12-20.

Sheets-Johnstone, M. (1999). The primacy of movement. Amsterdam: John Benjamins Publishing Company.

Smits, D.W., Gorter, J.W., Ketelaar, M.; Van Schie, P.E., Dallmeijer, A.J., Lindeman, E. \& Jongmans, M.J. (2010). Relationship between gross motor capacity and daily-life mobility in children with cerebral palsy. Dev Med Child Neurol, 52(3), e60.dal

Sorsdal, A.B., Moe-Nilssen, R., Kaale, H.K., Rieber, J. \& Strand, L.I. (2010). Change in basic motor abilities, quality of movement and everyday activities following intensive, goaldirected, activity-focused physiotherapy in a group setting for children with cerebral palsy. BMC Pediatr, 27, 10-26. 
Steinsholt, K. \& Sommerro, H. (2006). Improvisasjon. Kunsten å sette seg selv på spill. [Improvisation: the art of putting oneself at risk]. N.W. Norway: Damm \& Søn AS.

Todes, S. (2001). Body and world. Cambridge, Massachusetts, and London, England: MIT Press.

Van Eck, M., Dallmeijer, A.J., Voorman, J.M. \& Becher, J.G. (2009). Longitudinal study of motor performance and its relation to motor capacity in children with cerebral palsy. Dev Med Child Neuro, 51(4), 303-10.

Van Manen, M. (1990). Researching lived experience: human science for an action-sensitive pedagogy. New York: State University of New York Press.

Wigerstrand, S.R.(2006) Tenk fort! [Think fast!]. K Steinsholt \& H. Sommerro (Eds), Improvisasjon. Kunsten å sette seg selv på spill (pp. 95-115). Norway: N.W. Damm \& Søn AS.

Østern, T. P. (2006) Dansens uutholdelige letthet.[The unbearable lightness of dance]. K Steinsholt \& H. Sommerro (Eds.), Improvisasjon. Kunsten å.sette seg selv på spill (pp. 189-213). Norway: N.W. Damm \& Søn AS 